\title{
Value of the Jirgl flocculation test in the diagnosis of jaundice
}

\author{
D. P. ROSE' AND M. C. O'SHAUGHNESSY \\ From the Department of Chemical Pathology, United Sheffield Hospitals
}

SYNOPSIS The Jirgl flocculation test has been compared with the combination of the thymol reactions and serum alkaline phosphatase determination recommended by Maclagan in the investigation of 68 patients with jaundice. The test was found to be of value in distinguishing biliary obstruction from other causes of jaundice, but failed to distinguish between extrahepatic and intrahepatic biliary obstruction.

Serum glutamic oxalacetic transaminase and serum glutamic pyruvic transaminase estimations were performed in a number of cases, but were found to be of no value in the diagnosis of jaundice.

Jirgl (1957) observed that the serum of patients with obstructive jaundice became turbid and formed a precipitate on the addition of Folin-Ciocalteau phenol reagent. A positive reaction occurred in 44 of 46 patients with extrahepatic obstructive jaundice. The test was negative in 147 cases of infective hepatitis. Daikos, Mattheou, and Athanasiadou (1959) confirmed Jirgl's findings. Shimaoka and Firat (1962) found the reaction to be of value in the diagnosis of obstructive jaundice, and in particular for distinguishing between extrahepatic biliary obstruction and other causes of jaundice. Bell and Williams (1964), however, found consistently positive reactions in cases of chronic intrahepatic cholestasis.

The thymol turbidity and flocculation tests and the serum alkaline phosphatase estimation, used in combination, have been shown to distinguish

${ }^{1}$ Present address: University Department of Chemical Pathology, Royal Infirmary, Sheffield, 6.

Received for publication 3 May 1965. obstructive from non-obstructive jaundice in the majority of cases (Maclagan, 1947). Maclagan's criteria for obstructive jaundice are a serum alkaline phosphatase level of greater than 34 King-Armstrong units, together with normal thymol reactions.

In the present investigation the Jirgl flocculation test has been compared with the combined results of the thymol reactions and serum alkaline phosphatase determination, as a method of diagnosing obstructive jaundice, and has also been assessed as a means of distinguishing between extrahepatic biliary obstruction and intrahepatic cholestasis.

Serum glutamic oxalacetic transaminase and serum glutamic pyruvic transaminase estimations were carried out in the majority of cases, and the urine was tested for bilirubin and excess urobilinogen.

\section{METHODS AND MATERIAL}

The Jirgl flocculation test was carried out as modified by

TABLE I

COMPOSITION OF PATIENTS INCLUDED IN THE PRESENT STUDY

\begin{tabular}{|c|c|c|c|}
\hline Obstructive Jaundice & $\begin{array}{l}\text { No. of } \\
\text { Cases }\end{array}$ & Hepatic Jaundice & $\begin{array}{l}\text { No. of } \\
\text { Cases }\end{array}$ \\
\hline $\begin{array}{l}\text { Stones in the common bile duct } \\
\text { Presumed stone in common bile duct (stones in } \\
\text { gall bladder at laparotomy) } \\
\text { Post-cholecystectomy jaundice } \\
\text { Carcinoma of head of pancreas } \\
\text { Carcinoma of gall bladder } \\
\text { Carcinomatosis with liver metastases } \\
\text { Intrahepatic obstruction of unknown aetiology } \\
\text { (diagnosis by liver biopsy) }\end{array}$ & $\begin{array}{r}10 \\
3 \\
3 \\
14 \\
1 \\
10 \\
1\end{array}$ & $\begin{array}{l}\text { Infective hepatitis } \\
\text { Cirrhosis } \\
\text { Chlorpromazine jaundice } \\
\text { Hodgkin's disease } \\
\text { Hepatic fibrosis associated with ulcerative colitis } \\
\text { Total number of cases }\end{array}$ & $\begin{array}{r}10 \\
6 \\
4 \\
5 \\
1 \\
26\end{array}$ \\
\hline Total number of cases & 42 & & \\
\hline
\end{tabular}


TABLE II

RESULTS FOR OBSTRUCTIVE JAUNDICE

Clinical Diagnosis

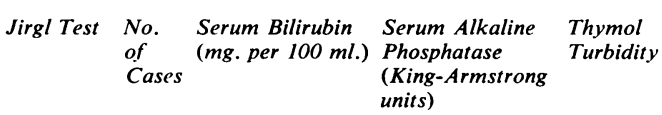

Thymol Flocculation

Means of

Gallstones in common bile duct

A.P. $>34$

T.R. normal

A.P. $>34$

T.R. normal

A.P. $<34$

T.R. normal

A.P. $<34$

T.R. abnormal

$\begin{array}{lll}\text { Positive } & 4 & 5 \cdot 4-8 \cdot 0 \\ \text { Negative } & 1 & 2 \cdot 4 \\ \text { Positive } & 4 & 3 \cdot 6-10 \cdot 8 \\ & & 5 \cdot 5\end{array}$

35-124

40

23-33

30

Gallstones in gall bladder (presumed duct obstruction)

A.P. $>34$

T.R. normal

A.P. $<34$

Positive $2 \quad 4 \cdot 6,4 \cdot 8$

Negative $\quad 1 \quad 4.4$

38-110

26

Post-cholecystectomy jaundice

Stone in the common bile duct

A.P. $>34$

T.R. normal

$\begin{array}{lll}\text { Positive } & 1 & 7 \cdot 0\end{array}$

67

Positive $\quad 1 \quad 11.0$

27

22

Positive

$6 \cdot 0$

$\begin{array}{lll}\text { Positive } & 8 & 3 \cdot 4-17 \cdot 7\end{array}$

35-144

Negative $2 \quad 4 \cdot 0,17 \cdot 0$

59,50

Positive $\quad 2 \quad 9 \cdot 4,17 \cdot 6$

23,30

A.P. $<34$

T.R. normal

A.P. $>34$

T.R. abnormal

A.P. $<34$

Positive $\quad 1 \quad 4.3$

136

$\begin{array}{lll}\text { Positive } & 1 & 16.2\end{array}$

32

Positive $\quad 1 \quad 5 \cdot 2$

64

Positive $4 \quad 4 \cdot 6-10 \cdot 6$

42-116

$\begin{array}{lll}\text { Negative } \quad 1 & 23.6\end{array}$

Positive $2 \quad 6.0,14.0$

40

T.R normal

A.P. $>34$

T.R. abnormal

Positive $2 \quad 2 \cdot 9,9 \cdot 2$

35-96

A.P. $<34$

T.R. normal

A.P. $<34$

$\begin{array}{lll}\text { Negative } & 1 & 2 \cdot 1\end{array}$

24-30

17

$1-2$
1
$1-2$
3

Negative

Negative

Negative

$+$

Confirmation

T.R. normal

nown aetiology

Intrahepatic
A.P. $>34$

Negative

Operation

Negative

Operation

T.R. normal

$$
\text { atase }
$$

A.P. $=$ serum alkaline ph
T.R. $=$ thymol reactions 
Shimaoka and Firat (1962). The serum bilirubin was determined by the method of King and Coxon (1950), the thymol reactions by the method of Maclagan (1944, 1947), and the serum alkaline phosphatase by the method of Kind and King (1954). The serum glutamic oxalacetic transaminase and serum glutamic pyruvic transaminase were estimated by the method of King (1958).

Sixty-eight patients with a serum bilirubin greater than $2 \mathrm{mg}$. per $100 \mathrm{ml}$. were studied. When available the final diagnosis was established by operation, biopsy, or postmortem examination findings, but in some cases it had to be made by means of the clinical picture, and the course of the disease.

The final diagnoses of the 68 patients are shown in Table I.

\section{RESULTS}

The results obtained are shown in Table II (obstructive jaundice) and Table III (hepatic jaundice). The cases included in Table II would be expected to give a positive Jirgl flocculation test, and those in Table III a negative test. In the tables each of the diagnostic categories has been subdivided according to the results of the serum alkaline phosphatase determinations, the thymol reactions, and the result of the Jirgl flocculation test.

OBSTRUCTIVE JAUNDICE Forty-two patients were diagnosed as having obstructive jaundice, and of these $36(86 \%)$ had positive Jirgl tests. The thymol reactions and serum alkaline phosphatase results were consistent with a diagnosis of obstructive jaundice, according to Maclagan's criteria, in 25 of the 42 patients $(59 \%)$. Twenty-one of these 25 had positive Jirgl flocculation tests. In 17 cases, either the thymol reactions or the alkaline phosphatase gave results which did not conform to Maclagan's criteria for obstructive jaundice, and of these, 15 cases had positive Jirgl tests. In only two cases (5\%) neither the thymol reactions and the serum alkaline phosphatase taken together, nor the Jirgl test, indicated correctly the nature of the jaundice.

HEPATIC JAUNDICE There were 26 patients with a final diagnosis of hepatic jaundice (Table III). Ten

TABLE III

RESULTS IN HEPATIC JAUNDICE

\begin{tabular}{|c|c|c|c|c|c|c|c|}
\hline Clinical Diagnosis & Jirgl Test & $\begin{array}{l}\text { No. } \\
\text { of } \\
\text { Cases }\end{array}$ & $\begin{array}{l}\text { Serum Bilirubin } \\
\text { (mg. per } 100 \mathrm{ml} .)\end{array}$ & $\begin{array}{l}\text { Serum Alkaline } \\
\text { Phosphatase } \\
\text { (King-Armstrong } \\
\text { units) }\end{array}$ & $\begin{array}{l}\text { Thymol } \\
\text { Turbidity }\end{array}$ & $\begin{array}{l}\text { Thymol } \\
\text { Flocculation }\end{array}$ & $\begin{array}{l}\text { Means of } \\
\text { Confirmation }\end{array}$ \\
\hline
\end{tabular}

Infective hepatitis

A.P. $<34$

T.R. abnormal

A.P. $<34$

T.R. abnormal

A.P. $>34$

T.R. abnormal

$\begin{array}{llll}\text { Negative } & 6 & 2 \cdot 0-20 \cdot 8 & 13-24 \\ \text { Positive } & 3 & 6 \cdot 5-9 \cdot 2 & 26 \\ \text { Negative } & 1 & 6.0 & 35\end{array}$

Cirrhosis

A.P. $<34$

T.R. abnormal

A.P. $<34$

T.R. normal

A.P. $>34$

T.R. abnormal

$\begin{array}{lllc}\text { Negative } & 3 & 2 \cdot 1-3.6 & 14-19 \\ \text { Negative } & 1 & 3.7 & 8 \\ \text { Positive } & 2 & 3.7,17.2 & 60,28\end{array}$

Chlorpromazine jaundice

A.P. $>34$

T.R. normal

A.P. $<34$

T.R. normal

A.P. $<34$

T.R. normal

4-19 6-12

1-12

+ to $++t+\quad \begin{aligned} & \text { Necropsy } 1 \\ & \text { Not confirmed } 5\end{aligned}$

12

4

$+++$

Not confirmed 2

Partial

Necropsy

Hodgkin's disease with hepatic involvement

Hodgkin's
A.P. $>34$

T.R. normal

A.P. $<34$

T.R. normal

A.P. $<34$

T.R. normal

A.P. $<34$

T.R. normal

$\begin{array}{lll}\text { Positive } & 1 & 4 \cdot 8 \\ \text { Positive } & 1 & 2 \cdot 8\end{array}$

84

10

Negative $2 \quad 3 \cdot 4,13 \cdot 2$

15,28

6-1

4, 1

Necropsy 1

8

60,28

Negative

Operation

+ , Negative

Biopsy 2

Hepatic fibrosis associated with ulcerative colitis A.P. $<34$

T.R. normal

$\begin{array}{lcc}\text { Positive } & 2 & 11 \cdot 2,16 \cdot 8 \\ \text { Positive } & 1 & 17 \cdot 6 \\ \text { Negative } & 1 & 4 \cdot 0 \\ \text { Negative } & 1 & 17 \cdot 6\end{array}$

$35-76$
23
20
28

Negative

Not confirmed

Negative

Not confirmed

Negative

Not confirmed

T.R. normal

Negative

$8 \cdot 8$

22

$\begin{array}{ll}\text { Negative } & \text { Necropsy } \\ \text { Negative } & \text { Necropsy } \\ \text { Negative } & \text { Not confirmed } \\ \text { Negative } & \text { Necropsy }\end{array}$

Negative

Necropsy 
patients had positive Jirgl tests. Six patients, including five of those with a positive Jirgl test, had serum alkaline phosphatase levels of greater than 34 King-Armstrong units on at least one occasion.

SERUM TRANSAMINASE RESULTS These were determined in 27 of the cases of obstructive jaundice. The serum glutamic oxalacetic transaminase (S.G.O.T.) results ranged from 45 to $345 \mathrm{King}$ units (mean: 190 , less than 100 in seven; 100 to 150 in five; over 150 in 15 cases), and the serum glutamic pyruvic transaminase results ranged from 30 to $370 \mathrm{King}$ units (mean: 168, less than 100 in six; 100 to 150 in five; over 150 in 16 cases). They were also estimated in 10 cases of parenchymatous liver disease. The S.G.O.T. ranged from 105 to $420 \mathrm{King}$ units (mean: 223,100 to 150 in two, over 150 in eight cases), and the S.G.P.T. ranged from 85 to $415 \mathrm{King}$ units (mean 220, less than 100 in one, 100 to 150 in four, over 150 in five cases).

URINARY BILIRUBIN AND UROBILINOGEN These were tested for in the majority of cases. All of the 20 patients with obstructive jaundice tested had bilirubin in the urine, and 10 also had urobilinogen present in excess amounts. All but two of eight patients with parenchymatous liver disease tested had bilirubin and excess of urobilinogen in the urine.

\section{DISCUSSION}

Shimaoka and Firat (1962) found the Jirgl flocculation test to be positive in 27 of 31 cases of extrahepatic obstructive jaundice and negative in 48 of 54 patients with jaundice not associated with extrahepatic biliary obstruction. Comparing the test with several other tests of liver function, including the cephalin flocculation test and the serum alkaline phosphatase level, these authors concluded that the Jirgl test was at least as valuable as these others in distinguishing between obstructive and non-obstructive jaundice. In the group without biliary obstruction Shimaoka and Firat included patients with metastatic carcinoma, lymphoma, and hepatoma in whom there was no evidence of extrahepatic obstruction. The Jirgl flocculation test was positive in only one of these cases. It follows from these results that the Jirgl test should be of value in distinguishing between extrahepatic obstructive jaundice and jaundice due to other causes, a distinction of considerable importance with regard to possible surgical intervention. Bell and Williams
(1964), on the other hand, have reported positive Jirgl reactions in 21 cases of primary biliary cirrhosis and in two cases of chlorpromazine jaundice.

In the present study four cases of Hodgkin's disease examined at necropsy showed no apparent $\overline{\bar{s}}$ occlusion of the extrahepatic biliary system, but $\mathbb{D}$ there was histological evidence of intrahepatic $\varrho$ obstruction. Three of these cases gave positive Jirgl is tests. The patient with intrahepatic obstruction of $\overrightarrow{0}$ unknown aetiology also had a positive Jirgl reaction. $\vec{\overrightarrow{ }}$ To these cases may be added two of the four patients $\vec{\omega}$ with cholestatic jaundice due to chlorpromazine $\rightarrow$ sensitivity. Both of the cases of chlorpromazine? jaundice studied by Bell and Williams (1964) gave $\vec{\infty}$ positive Jirgl reactions and so the test is clearly of

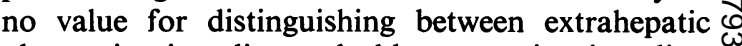
obstructive jaundice and chlorpromazine jaundice. Three of the patients with infective hepatitis had a positive Jirgl test. This may have been the result of $z$ cholangiolar obstruction.

The results of the study reported here, like those obtained by Bell and Williams (1964), fail to confirm the findings of Shimaoka and Firat (1962) that the Jirgl flocculation test is of value in distinguishing $\vec{\bullet}$ between extrahepatic obstructive jaundice and cases of in which obstruction may be present within the liver substance.

It appears, from the small series of cases studied, that the Jirgl flocculation test is at least as valuable as the combination of thymol reactions and serum alkaline phosphatase level in distinguishing between obstructive and non-obstructive jaundice. No single test is as yet available for making this distinction and laboratory assessment requires a series of tests. It is suggested that the Jirgl flocculation test is a valuable addition to those already available.

The serum transaminase estimations did not $\frac{0}{0}$ appear to be of value for distinguishing between jaundice due to obstruction and that due to paren- 8 chymatous liver disease.

We are grateful to Dr. Arthur Jordan for suggesting this investigation, and for much helpful advice during the course of the study and preparation of the paper.

\section{REFERENCES}

Bell, J. L., and Williams, R. (1964). J. clin. Path., 17, 47. Daikos, G. K., Mattheou, P., and Athanasiadou, M. (1959). Lancet, 2, 488.

Jirgl, V. (1957). Klin. Wschr., 35, 938.

Kind, P. R. N., and King, E. J. (1954). J. clin. Path., 7, 322.

King, E. J., and Coxon, R. V. (1950). Ibid., 3, 248.

King, J. (1958). J. med. Lab. Technol., 15, 17.

Maclagan, N. F. (1944). Brit. J. exp. Path., 25, 234.

- (1947). Brit. med. J., 2, 197.

Shimaoka, K., and Firat, D. (1962). Arch. intern. Med., 109, 270. 